\title{
A Cost-Effectiveness Study of Ownership versus Access
}

\author{
Valerie J. Payne \\ Mary A. Burke
}

\begin{abstract}
This paper describes a method which was used to evaluate the cost-effectiveness of three different ways of supplying periodical articles in an academic library. The methods considered were: subscribing to a periodical title (ownership); individual article supply provided by two electronic document delivery services, ArticlesFirst of OCLC FirstSearch and UnCover; and traditional article supply through the British Library Document Supply Centre. The operational costs of the alternatives are obtained by taking a management accounting approach and are examined in relation to the provision of the services within the library of St. Patrick's College, Maynooth, Ireland. The cost-per-use of owning a periodical title is calculated based on the operational costs of the Periodicals Department of the library, its subscription price and a lifetime use determined by examination of the current requests for articles made through the library's Inter-Library Loans Department. The cost-peruse for the other services are also calculated based on their operational costs and document delivery charges. [Article copies available for a fee from The Haworth Document Delivery Service: 1-800-342-9678. E-mail address: getinfo@haworth.com]
\end{abstract}

\section{INTRODUCTION}

Academic libraries in the 1980s and 1990s have been faced with the problem of rising periodical prices, a decline in library budgets, and rapid

Valerie J. Payne is the Periodicals Librarian, St. Patrick's College, Maynooth, Co. Kildare, Ireland. Mary A. Burke is the Head of the Department of Library and Information Studies, University College, Dublin, Ireland.

This paper is based on a minor thesis submitted in partial fulfillment of the requirements for the degree of Master in Library and Information Studies.

The Serials Librarian, Vol. 32(3/4) 1997

(C) 1997 by The Haworth Press, Inc. All rights reserved. 
growth in research material. This has meant that a gap has emerged between the range of titles libraries would like to hold and what they can afford to hold. As a result many libraries are re-thinking their collection maintenance policy in terms of 'access' to periodical titles rather than the acquisition of all relevant titles. The phrase 'just-in-case' (ownership) has been coined to refer to the traditional policy of holding a title which may be required, and 'just-in-time' (access) to refer to the acquisition of the article when it is requested by a user. In the past, if a library did not hold a particular title in its collection it could either apply directly to a library which did, or to institutions such as the British Library Document Supply Centre (BLDSC) or OCLC, for a photocopy of the article required. The advent of Electronic Document Delivery (EDD) Services in the early 1990s has provided another option. These services provide electronic access to current awareness/alerting services (CAS) which reproduce the contents pages of the periodical titles which they hold and, once articles have been identified, deliver documents through their Individual Article Supply (IAS).

Inherent in this rethinking of collection management policy is the idea that changing from 'just-in-case' to 'just-in-time' will bring about savings for libraries, that the cost of acquiring articles from a journal will be less than subscribing to a title. If this is not the case then the cancellation of a title has not achieved its objective of saving the library money. Conversely, if the library does not hold a title that is in heavy demand and it is costing more in document delivery charges than in subscription charges, then clearly it should be taken on as a subscription. This research is mainly concerned with the latter consideration and by comparing the costs involved in three different methods of article supply, it will ascertain to what periodical titles, if any, subscription should be initiated.

The library at St. Patrick's College, Maynooth, Ireland (Maynooth College) has been used as the source of data for this study and the conclusions drawn are related directly to that library but we believe that the methods described here have general application. The study was carried out in early 1996. The planning time framework will be considered as short term, that is five years. This is for two reasons: the changes taking place in serial publishing make it difficult to predict in what form or forms periodicals will appear in the next century; and secondly, if funding allows, a library extension is to be built in Maynooth in the year 2000 . 


\section{METHODOLOGY}

The three methods to be compared are:

1. Subscribing to a periodical title and holding it within a Periodicals collection. The articles are supplied from the collection when required by a user.

2. Using Individual Article Supply (IAS) of Electronic Document Delivery Services. Two services will be examined, the document delivery services of ArticlesFirst on the OCLC FirstSearch database and UnCover.

3. Providing an inter-library loans service that obtains photocopies of articles from the British Library Document Supply Centre and other institutions through the medium of British Library forms.

The first two methods of article supply will be examined in some detail: providing a description of the method used to derive costs and summarising all costs. Only a summary of the costs will be given for method 3 as the method of derivation is similar to that used for methods 1 and 2 .

Four main issues have to be addressed in developing a methodology for comparing the three different methods of article supply considered. These are:

a. The alternatives being compared are very different and do not provide identical services.

b. A method of costing and evaluating these alternatives must be selected.

c. A method of predicting the use of a periodical title over its life time must be chosen to enable a cost-per-use of holding a periodical title to be established for comparison with the cost-per-use of the other methods of article supply.

d. A decision on which costs should be included in the cost analysis must be made.

The first issue will not be addressed directly here: this article concentrates instead on methods of costing the alternatives. We have to acknowledge that even though we choose to ignore issue (a) here, this may well be the ultimate factor in deciding which alternative is selected. For example, the prestige accorded to an institution in holding a 'substantial' periodical collection, rather than making articles available through an EDD service or ILL, may be a significant factor in choosing ownership over access. Other non-monetary measures of effectiveness such as the coverage, the 
response time, the user friendliness, the delivery reliability and the quality of articles provided by the alternatives may also have a significant impact on the alternative selected.

The technique selected to cost and evaluate the alternatives is cost-effective analysis and it has been used previously in similar studies. (Milne and Tiffany 1991a; Lancaster 1971). It is a tool which helps a decisionmaker to identify a preferred choice amongst possible alternatives (Quade $1967,1)$. The basic criterion that will be used to rank the alternatives will be cost-per-use, this cost-effectiveness technique was used by Milne and Tiffany in their study of the library at the Memorial University of Newfoundland, Canada (Milne and Tiffany 1991a; 1991b).

Costs are an essential part of this study but which costs should be included? Costs have to be considered in relation to the objectives to be achieved and the environment in which the study is being conducted. In this case the objective is to find the most cost-effective way of supplying articles by looking at some available alternatives. Milne and Tiffany related cost specifically to the annual subscription price and in so doing underestimated the total costs involved in owning a title. In this study all the costs including operational, subscriptions and document delivery charges involved in ownership and access will be considered. The environment is that of the Library at Maynooth College, where a Periodicals collection exists, an inter-library loans service is available and the College is already connected to the Internet.

\section{COST-PER-USE}

A cost-per-use will be derived for all alternatives and will provide a cost-effective monetary value for comparing the alternatives. When a subscription is taken out the cost of that subscription covers the repeated use of articles from that year's issue. If a title is never used costs have been needlessly incurred but if articles are used, the level of that use will determine its cost-effectiveness. The purpose of the Milne and Tiffany study was cancellation of periodical titles; the emphasis of this study is possible subscription, if the cost-per-use is less that the cost-per-use of access. The cost-per-use was obtained by dividing all the costs of ownership by a title's lifetime usage as ascertained through its ILL requests. It is recognised that one of the possible disadvantages of this approach is that it may underestimate the true demand for articles because users may not take the trouble to request or wait for ILLs.

Milne and Tiffany estimated the total number of uses that the issues purchased by the annual subscription price would receive by calculating 
the number of uses a year's issues would receive over its lifetime and then dividing the current annual subscription by that lifetime use. They obtained this lifetime use by tagging five back years of issues and extrapolating from the number of uses received by multiplying by an adjustment factor calculated from the half-life listings in the SCI Journal of Citations Reports. Journal Half-life Listing, Section 2 (Milne and Tiffany 1991a, 11). The lifetime use figure for this study will be obtained from ILL statistics of Maynooth College for the years 1990-1994. Users can potentially request articles from ILL for any back issues of a journal title, so that the requests for a title in a given year reflect its possible lifetime usage. This can be illustrated by reference to a title which appeared on the list of ILL requests for 1994. Taking the title Cancer Research as an example, three articles were requested from 1994 issues, three from 1993, two from 1992 , one from 1990, one from 1989, one from 1975-1984, and one from 1900-1974. This could represent a possible request pattern for issues published in 1994 and the sum total of all these requests its lifetime use.

The calculation of a cost-per-use for an EDD service or the BLDSC is simpler then that for ownership. When one uses either an EDD service or the BLDSC costs are only incurred when the article is requested, that is 'used,' so that the cost of an article can be directly related to its use. The cost-per-use of these document delivery services will be obtained by adding together not only the actual cost of an article but any other costs incurred in providing the article, e.g., costs involved in running an ILL department.

\section{COSTS}

There is an extensive amount of literature concerned with the process of how costs are calculated (Abels, Kantor and Saracevic 1996; Ford 1973; Hayes 1980; Hayes 1996; Hayes and Becker 1984; Kantor 1989; Magson 1973; Mason 1972; Shillinglaw 1989; Smith 1991; Smith and Schofield 1971). It is usual when conducting a cost study to carry out a cost accounting analysis to estimate the total cost of the provision of the particular service or services under investigation. In the library context, the cost accounting process has been used to estimate the full or total costs of providing a library service and for specific services within it. Costing specific services often leads to the calculation of a unit cost for the provision of these services by simply dividing the costs of the services for a period by the number of units produced in that period. The analysis of the alternative costs of article supply represents a special costing exercise to which a management accounting approach is more appropriate than a cost 
accounting one. Management accounting is concerned with providing information to people in an organisation for use in the decision making process and is often applied to decisions that are not routinely made as in the case of special studies. These special studies require only those costs that are relevant to the specific alternative courses under examination. Therefore, costs have to be classified according to whether they are relevant or irrelevant to a particular decision using the 'decision-relevant approach' (Drury 1992, 236).

\section{RELEVANT AND IRRELEVANT COSTS}

In order to find out which costs are relevant or irrelevant to this specific study it is necessary to consider the elements which make up the total costs of each alternative in order that they can be categorised. The total cost is composed of two elements, direct costs and indirect costs. This can be written as:

Direct Cost + Indirect Cost $=$ Total Cost. $($ Virgo 1987, 80)

The direct costs are those that are directly attributable to the service. These might include the personnel, materials and equipment directly involved in the provision of the service. The indirect costs are not attributable to any particular service and need to be arbritarily assigned. They include such things as the security service, the administrative staff in the library, the heating, electricity and rental of a building.

There are many problems involved in determining total costs; these include: the allocation of the indirect costs (also referred to as overheads); deciding which indirect costs should be included; the calculation of building and equipment costs and staffing costs (Hayes 1980; Clements 1984; Smith 1991). However, some of the problems associated with cost accounting can be minimised when one takes a management accounting approach and looks for only the relevant costs for each alternative. This becomes clearer if rather than viewing costs as direct and indirect another categorisation is used, namely fixed and variable costs. A fixed cost is one that does not change as the level of service changes and it also provides the capacity to carry out the service or services (Shillinglaw 1989). For example, if articles are supplied through EDD or through the BLDSC and a 'core collection' is still maintained, computers will still be needed to accession periodicals in that collection, and would be considered as fixed costs. Into this category fall many costs that would also be considered as 
indirect costs such as heating and electricity. A variable cost is one that does change as the volume of the services provided changes. For example, the total costs of the periodicals department will rise if more books are purchased but heating and electricity costs will only increase if more processing time is involved.

It is necessary to distinguish those costs which are fixed and those which are variable in order that the fixed costs can be eliminated from the cost analysis. This is done by examining each alternative and categorising the costs within each alternative firstly as either direct or indirect and then within those categories as either variable or fixed. The total variable costs can then be calculated and an average variable cost obtained for each alternative by dividing the total variable costs by the number of units, e.g., the number of periodical titles or inter-library loans.

\section{THE STUDY}

The cost-per-title per annum of owning a periodical title, which includes not only its subscription price but all the other costs involved in making a periodical available to staff and students, was identified for the Periodicals Department, Maynooth College. The processes and tasks involved in owning a periodical were identified and the associated labour, material, and equipment costs were calculated. These were listed as either direct or indirect costs, variable or fixed; variable costs were divided by the number of periodical titles currently taken and finally, all relevant costs were added together to obtain a cost-per-title. A summary of costs is given in Table 1.

It was found on average that the number of volumes needed to bind science journal titles was approximately two volumes annually and that for the other disciplines it was one volume for each title annually. Hence, two binding costs are given, one for science and one for the other disciplines.

Therefore, total annual cost-per-title equals:

Cost-per-title $=$ telephone + stationery + postage + binding + annual subscription

Cost-per-title $($ science $)=£ 18.32(\$ 28.95)+$ annual subscription

Cost-per-title (other) $=£ 9.43(\$ 14.90)+$ annual subscription

Having established the cost-per-title of ownership, the possible use that a title might receive over its lifetime was estimated using ILL requests made to the Inter-Library Loans Department of Maynooth College from 
TABLE 1. Summary of Periodical Costs

\section{SUMMARY OF COSTS}

Irrelevant Costs:

Relevant Costs:

$\begin{array}{lll} & \text { Costs } & \text { Cost-per-title } \\ \text { Labour costs (direct and indirect) } & \text { Telephone } & 11.5 \text { pence } \\ \text { Equipment (direct) } & \text { Stationery } & 11 \text { pence } \\ \text { Other indirect costs } & \text { Postage } & 31 \text { pence } \\ & \text { Binding (science) } & \text { f17.78 } \\ & \text { Binding (other) } & \text { f8.89 } \\ & \text { Annual subscription } & \text { Varies } \\ & \text { to periodical } & \end{array}$

1990-1994. The cost-per-title of ownership was then divided by its use to obtain a cost-per-use.

The demand for articles requested through the ILL Department was examined in great detail for the year 1994. A print-out of the inter-library loan applications was obtained from the Lancaster University loans management system used by the ILL Department to obtain a list of journal titles; titles with only one request were ignored because of their low request level in order to reduce the list of journal titles to a manageable size. These titles were then entered on a spreadsheet and the number of requests for individual titles were totalled. Articles requested in the years 1990-93 were also examined but in less detail; this was done to establish that titles with a large number of requests in 1994 were not just once-off titles of interest but had been consistently requested in other years. This resulted in a list of the twenty-one top requested titles as shown as Table 2. This table includes an average request (i.e., lifetime use) rate calculated for the years 1990-94 and the commencement date of publication for each title (Start Date).

The commencement date is an important consideration when calculating the possible lifetime use: the longer the run the greater the pool of back issues and therefore, the higher the possibility of article requests. However, the influence of long back runs is diminished by the fact that the use of articles published in a given year declines over time and this is indicated by a title's half-life. All the titles listed in Table 2 are scientific journals and have been published for at least twenty years, so that the possibility of underestimation of use, while present, is likely to be small. On the basis of this argument, no adjustment was deemed necessary to the estimate of lifetime use. 
尊

8

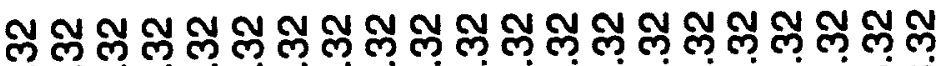

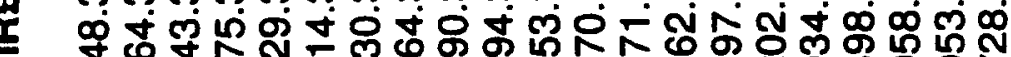
फ़

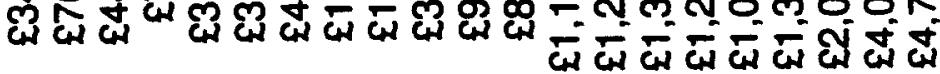

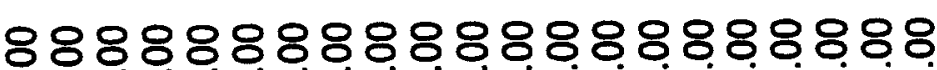

它以

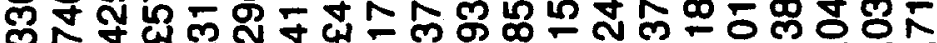

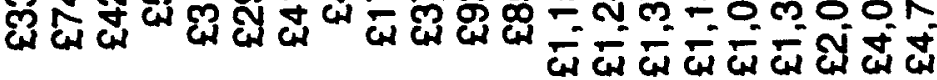

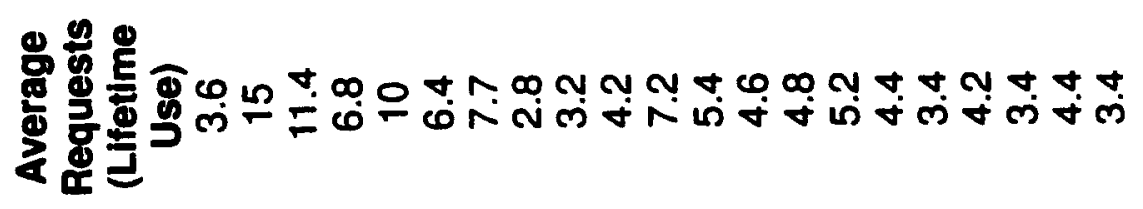

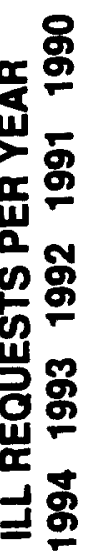

N - NFF"

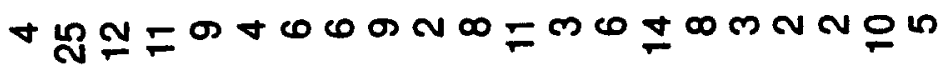

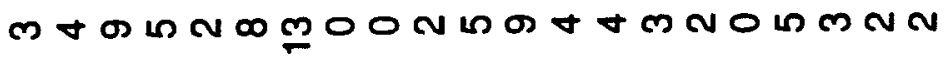

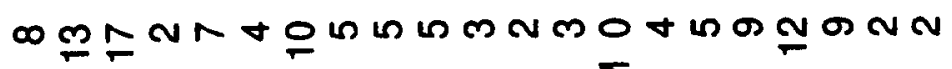


As only science titles were in the top twenty-one titles the cost-per-title (science) was added to the subscription costs to obtain total costs. Total costs were then divided by the average request (lifetime use) rate for each title to obtain a cost-per-use. Three of the titles included in Table 2 are marked invalid because the library currently subscribes to these titles and therefore, the level of demand for recent articles from these titles is underestimated. All the titles in Table 2 are scientific journals, although the original lists were cross-disciplinary. This is not surprising as scientific journals on average cost more than titles in the humanities and social sciences and although there may be a relatively high demand for some scientific titles the cost of their subscriptions makes them unattractive acquisitions.

The cost-per-article of the EDD services UnCover, ArticlesFirst of FirstSearch and the BLDSC were also determined. The cost components considered were not only the cost of the individual articles but the subscription, telecommunications, labour and equipment costs of the service. As in the case of ownership, costs were identified and listed as either direct or indirect, variable or fixed, and using the relevant and irrelevant criterion only relevant costs were used to calculate a cost-per-article. All individual values of cost-per-article were then totalled to obtain an average cost-per-article for the service. In these cases the cost-per-article is also the cost-per-use. An outline on how the cost-per-article/cost-per-use was determined is given only for UnCover (see Table 3), a summary only is given for the other two services.

\section{UNCOVER}

There are a number of annual subscription options available from UnCover ranging, at the time of the study, from free access to $£ 6,330.00$

TABLE 3. Summary of UnCover Costs

SUMMARY OF COSTS

The irrelevant costs were:

The relevant costs were:

Costs

Cost-per-article

Telecommunications (indirect)

UnCover fax

$\$ 16.73(£ 10.60)$

Labour costs (indirect)

Equipment (indirect) 
$(\$ 10,000)$. However, the subscription cost was excluded from the overall cost-per-use, as articles have to be identified from some source or sources and a cost incurred regardless of the document delivery service. Although the subscription cost-per-use has been ignored, it is possible to ascertain it and it can be used to compare the cost of the different current awareness services (Payne 1996, 74-80).

The document delivery arrangements for UnCover at the time of this study were simple, document delivery by fax only, with only one supplier. UnCover aims to deliver most articles within twenty-four hours and if articles are stored electronically, they are delivered within one hour anywhere in the world. Payment can either be made by credit card when the document is ordered or by establishing password-controlled deposit accounts against which documents are automatically deducted.

The cost of an UnCover document is composed of three elements: the service charge (i.e., the cost of retrieving and sending the document), copyright fee and a fax surcharge for customers outside the US and Canada. The service charge is a fixed fee, the fax surcharge to Ireland stands at $\$ 3.00$ but the copyright royalties vary according to the rates set by the publishers. In order to establish the average delivery cost-per-article fiftytwo titles were extracted from the 1994 list of inter-library loans; articles from these titles were then ordered, so that the charges would appear on the screen, and then immediately cancelled. This showed that the service charge was $\$ 8.50$ per article and that after the service charge was deducted from the cost-per-article that the copyright fees varied from $\$ 1.50$ for the American Journal of Sociology to $\$ 13.00$ for Leukaemia. When the fax surcharge was added onto the cost of an article the average cost-per-article was $\$ 16.73(£ 10.60)$. It is also important to note that although all the titles were located on the database, UnCover could only supply articles for $90.4 \%$ of the listed titles.

All the other costs including the telecommunications charges, equipment and labour costs incurred in the provision of the UnCover service were found to be fixed in relation to Maynooth College and therefore, were regarded as an irrelevant costs for the purpose of the study. For example, a PC connected to the Internet is needed to access UnCover but as the PCs were also used to access other databases, computer packages and the Internet, no extra cost was incurred in providing PC access to UnCover.

\section{SUMMARY OF ANALYSIS}

A summary of the cost-per-use of all the alternatives is given in the Table 4. Two titles with the lowest cost-per-use of ownership taken from 
TABLE 4. Summary of Cost-Per-Use of the Alternative Methods of Supply

\begin{tabular}{|c|c|}
\hline $\begin{array}{l}\text { Method of Delivery } \\
\text { Ownership } \\
\text { Journal of Nematology } \\
\text { Journal of Bacteriology }\end{array}$ & $\begin{array}{l}\text { Cost-per-use } \\
\{11.00(\$ 17.38) \\
£ 33.00(\$ 52.14)\end{array}$ \\
\hline $\begin{array}{l}\text { ArticlesFirst of FirstSearch } \\
\text { Fax } \\
\text { Mail }\end{array}$ & $\begin{array}{rr}£ 16.07 & (\$ 25.40) \\
£ 7.70 & (\$ 12.16)\end{array}$ \\
\hline $\begin{array}{l}\text { Uncover } \\
\text { Fax }\end{array}$ & $£ 10.60(\$ 16.75)$ \\
\hline $\begin{array}{l}\text { BLDSC } \\
\text { Standard Photocopy (Mail) } \\
\text { Urgent Action Fax } \\
\text { Copyright Cleared (Mail) }\end{array}$ & $\begin{array}{rr}£ 7.12 & (\$ 11.25) \\
£ 21.00 & (\$ 33.18) \\
£ 10.56 & (\$ 16.68)\end{array}$ \\
\hline
\end{tabular}

Table 2 are given and it can be seen that both are above the cost-per-use of the cheapest mail delivery provided by BLDSC but in terms of fax delivery the Journal of Nematology is just above UnCover and the BLDSC. Given that an ILL analysis of cost-per-use probably underestimates use and that the cost-per-use of the Journal of Nematology is significantly lower than the cost of fax delivery provided by two of the document delivery services, this title would appear to be a candidate for subscription (ownership). However, the other titles listed in Table 2 including the Journal of Bacteriology, which has the second lowest cost-per-use at $£ 33.00$ ( $\$ 52.14)$, have a cost-per-use well above the other alternatives and as such remain candidates for access only.

Therefore, if most titles listed in Table 2 can be discounted as possible future subscriptions, access will continue to be the method of article supply and by comparing the other access alternatives the cheapest cost-peruse can be found. If the cheapest cost-per-use is taken, than the BLDSC mail delivery is the cheapest but with the cost-per-use of ArticlesFirst being only slightly more expensive. However, if fax delivery is preferred UnCover is significantly cheaper than ArticlesFirst and much cheaper than the BLDSC. It should be noted that the fax cost-per-use of both UnCover and ArticlesFirst include a fax surcharge which is not paid by customers in the USA and Canada. Similarly, customers from North America requesting articles from the BLDSC would also incur a fax surcharge. 
Articles provided by UnCover are copyright cleared, however, BLDSC standard mail delivery are not and copyright cleared articles have to be requested separately. If the price of a BLDSC copyright cleared article is compared with the others, then ArticlesFirst is considerably cheaper and a faxed article provided by UnCover is the same price as a copyright cleared article delivered by mail.

\section{CONCLUSIONS}

The results of this study show that based on the cost-per-use of all the alternatives, access should continue to be the method of article supply for all but one title currently taken as ILLs in Maynooth College. In Maynooth, article supply by mail should continue to be provided by the BLDSC but consideration should be given to providing fax delivery through UnCover. Copyright cleared articles are rarely required by Maynooth users and therefore the selection of a supplier is not a major consideration.

The methodology and the results of this study can be used by other libraries but may need to be adapted to suit local circumstances, where costs and priorities may be different from those at Maynooth College. In the case of Maynooth College, the introduction of an EDD service has no relevant cost impact because the telecommunications, equipment and staffing infrastructure already exists but this may not be the case for other libraries. It is also very difficult to decide between the alternatives purely on the basis on cost-per-use alone without considering other measures of effectiveness, such as the different speed of document delivery offered by fax over mail delivery, the quality of the copies provided by the different services or the speed of Internet access, which may influence a library's selection of an article supplier. For example, in some organisations where speed of delivery may be a prime consideration, UnCover would appear to be a very attractive option as it has the cheapest cost-per-use for fax delivery but what may be gained by speedy delivery may be lost in terms of the quality of the faxed over the photocopied article. However, a decision on whether a title should be 'owned' or 'accessed' has to be decided on rational grounds and the cost-per-use approach provides a base on which rational decisions can be made.

\section{REFERENCES}

Abels, E.G., P.B. Kantor and T. Saracevic. 1996. "Studying the cost and value of library and information services: applying functional cost analysis to the library in transition," Journal of the American Society for Information Studies 47, no. 3: 217-227. 
Clements, D.W.G. 1984. "Costing of library systems," in Costing and the economics of library and information services, edited by S.A. Roberts, Aslib Reader, vol. 5, 8-25. London: Aslib.

Drury, C. 1992. Management and cost accounting. 3rd ed. New York: Chapman \& Hall.

Ford, G. 1973. Library automation: guidelines to costing. Lancaster: Office for Scientific and Technical Information.

Hayes, S. 1980. "What does it really cost to run your library?," Journal of Administration 1, no. 2: 1-10.

Hayes, R.M. 1996. "Cost of electronic reference resources and LCM: the library costing model," Journal of the American Society for Information Science 47, no. 3: 228-234.

Hayes, R.M. and J. Becker. 1984. "Cost accounting in libraries," in Costing and the economics of library and information services, edited by S.A. Roberts, Aslib Reader, vol. 5, 8-25. London: Aslib.

Kantor, P.B. 1989. "Library cost analysis," Library Trends 38, no. 2. Fall: 171-188.

Lancaster, F.W. 1971. "The cost-effectiveness analysis of information retrieval and dissemination systems," Journal of the American Society for Information Science Jan-Feb: 12-27.

Magson, M.S. 1973. "Techniques for the measurement of cost-benefit in information centres," Aslib Proceedings 25. no. 5: 164-185.

Mason, D. 1972. "PPBS: applications to an industrial information and library service," Journal of Librarianship 4, no. 2: 91-105.

Milne, D. and B. Tiffany. 1991a. "A cost-per-use for evaluating the cost-effectiveness of serials: a detailed discussion of methodology," Serials Review 17, no. 2: 7-19.

Milne, D. and B. Tiffany. 1991b. "A survey of the cost-effectiveness of serials: a cost-per-use method and results," Serials Librarian 19, nos. 3/4: 137-149.

Payne, V.J. 1996. "A cost-effective study of ownership versus access: A case study for St. Patrick's College, Maynooth." A thesis submitted in partial fulfillment of the requirements for the degree of Master in Library and Information Studies., Department of Library and Information Studies, University College Dublin.

Quade, E.S. 1967. "Introduction and overview" in Cost-effectiveness analysis: a new approach to decision-making, edited by T.A. Goldman, 1-16. New York: Praeger.

Shillinglaw, G. 1989. "Costing methods and applications," in Cost-effectiveness technical services, edited by G.M. Pitkin, 5-21. New York: Neal-Schuman.

Smith, G.C.K. and J.L. Schofield. 1971. "Administrative effectiveness: time and costs of library operations," Journal of Librarianship 3, no. 4: 245-66.

Smith, G.S. 1991. Managerial accounting for libraries and not-for-profit organisations. Chicago: American Library Association.

Virgo, J.A. 1987. "Costing and pricing information services," Drexel Library Quarterly 21, no. 3: 75-98. 